\title{
Pichia antillensis, a New Species of Yeast Associated with Necrotic Stems of Cactus in the Lesser Antilles
}

\author{
WILLIAM T. STARMER, ${ }^{1}$ HERMAN J. PHAFF, ${ }^{2 *}$ JOANNE TREDICK,${ }^{2}$ MARY MIRANDA, ${ }^{2}$ AND VIRGINIA \\ ABERDEEN ${ }^{1}$ \\ Department of Biology, Syracuse University, Syracuse, New York $13210^{1}$ and Department of Food Science and \\ Technology, University of California, Davis, California $95616^{2}$
}

\begin{abstract}
We describe Pichia antillensis, a new species of yeast which is closely related to Pichia opuntiae. Pichia antillensis, 20 strains of which were isolated, is heterothallic and occurs in nature in both the haploid state and the diploid state. It produces asci with four hat-shaped spores, which are rapidly released upon maturity. The guanine-plus-cytosine content of its nuclear deoxyribonucleic acid is 33.4 to $33.7 \mathrm{~mol} \%$. The deoxyribonucleic acids of Pichia antillensis and Pichia opuntiae var. opuntiae show approximately $50 \%$ homology, but the two species are not interfertile. Moreover, the two species are separated geographically and by host plant. Pichia antillensis occurs principally in necrotic tissue of the columnar cactus Cephalocereus royenii in the West Indies, and Pichia opuntiae var. opuntiae occurs in Opuntia rots in Australia. The type strain of $P$. antillensis is strain UCD-FST 82-651A (= ATCC 56267 = CBS 7111).
\end{abstract}

Recently, we have been studying a collection of yeasts that were obtained from decaying stems of cacti growing on islands in the Caribbean Sea. In this collection we discovered a heterothallic yeast which has a low-level physiological profile, a deoxyribonucleic acid (DNA) base composition of 33.4 to 33.7 mol\% guanine plus cytosine $(\mathrm{G}+\mathrm{C})$, and, as far as now known; a restricted geographic and host plant distribution. The sexual, physiological, and macromolecular properties of this yeast are similar to those of three previously described cactus-specific yeasts, Pichia heedii (9), Pichia amethionina (13), and Pichia opuntiae (14), which are known from other geographic regions. Comparisons of the new isolates with strains of these three previously described species for sexual compatibility, physiological abilities, ecological specificity, and DNA-DNA sequence homology suggested that the new isolates comprise a new species in the genus Pichia. We named the new isolates Pichia antillensis because of their unique habitat in necrotic tissues of the columnar cactus Cephalocereus royenii on several islands of the Lesser Antilles.

\section{MATERIALS AND METHODS}

Samples of necrotic cactus tissue yielding the new yeast were collected from islands in the eastern West Indies in May 1982 (Table 1) during cruise CF-8205 of the research vessel Cape Florida in this region. The techniques used for yeast isolation and purification have been described previously (12). The yeast strains analyzed for nuclear DNA base composition and the strains used in the DNA-DNA homology sequence studies are listed in Table 2.

The usual phenotypic characterization of the isolates was carried out by methods currently used in yeast taxonomy (16), but additional carbon compounds used in assimilation tests were also employed. These included D-glucosamine hydrochloride, $N$-acetyl-D-glucosamine, methanol, 2-propanol, acetone, and ethyl acetate; the last three compounds could be tested only by incorporating them at concentrations of $1.0 \%$ in yeast nitrogen base agar because in liquid yeast nitrogen base media they proved to be inhibitory, even in those cases where good growth occurred on solid media.

DNA extraction and purification were carried out by the methods described by Price et al. (10), except that purified

\footnotetext{
* Corresponding author.
}

DNA was concentrated by electrophoresis in a concentrator (ISCO, Lincoln, Nebr.) and the reference DNA was labeled with ${ }^{125} I$ as described by Holzschu et al. (5). The $G+C$ contents of the nuclear DNAs were calculated from buoyant density values in cesium chloride gradients established in a Spinco model $\mathrm{E}$ analytical ultracentrifuge equipped with photographic optics $(11,15)$ and were based on three separate determinations. DNA from Micrococcus luteus strain 2039 (International Collection of Phytopathogenic Bacteria, Department of Bacteriology, University of California, Davis), with a buoyant density of $1.7310 \mathrm{~g} / \mathrm{ml}$, was used as a reference. The buoyant density of the Micrococcus luteus DNA was derived from comparison with plasmid-free Escherichia coli K-12 DNA, the buoyant density of which was taken to be $1.7100 \mathrm{~g} / \mathrm{ml}$. Denaturation of DNA, incubation for reassociation, and analysis of the renaturation kinetics, reannealing reactions, and quantitation of single- and double-stranded DNAs were carried out according to the protocol of Price et al. (10). Samples were counted with a NuclearChicago model 1185 gamma ray counter ( $90 \%$ efficiency).

Single ascospores were isolated from mature asci with a micro-manipulator (2).

\section{RESULTS}

The physiological and morphological properties of the strains listed in Table 1 resembled those of $P$. opuntiae (14), and the nuclear DNA base compositions of these strains (Table 2) were close to values for $P$. opuntiae, $P$. heedii (9), and $P$. amethionina (13), all of which have as their habitat the necrotic tissues of cacti. These similarities induced us to carry out DNA-DNA base sequence homology studies (Table 3). The results of these experiments indicate that $P$. antillensis appears to be closely related to $P$. opuntiae var. opuntiae and distantly related to $P$. opuntiae var. thermotolerans, but not significantly related to $P$. heedii or $P$. amethionina. Because no conjugation was observed in our laboratory between haploid mating types of heterothallic $P$. antillensis and $P$. opuntiae, the strains of $P$. antillensis are described here as a new species.

Latin diagnosis of Pichia antillensis sp. nov: In extracto malti cellulae ovoideae, $1.6-5.3 \times 2.1-5.8 \mu \mathrm{m}$, singulae, binae, aut in catenis brevis; annulus et sedimentum tenuis formantur; pellicula nulla.

Cultura in agaro malti post dies $14\left(25^{\circ} \mathrm{C}\right)$ demissa con- 
TABLE 1. Strain numbers, mating types, localities, and cactus hosts of isolates studied

\begin{tabular}{|c|c|c|c|}
\hline $\begin{array}{l}\text { UCD-FST } \\
\text { strain no }\end{array}$ & $\begin{array}{l}\text { Mating } \\
\text { type }\end{array}$ & Locality & Host plant \\
\hline $82-544$ & h- & Fox Bay, Montserrat & $\begin{array}{l}\text { C. royenii }(\mathrm{L} .) \\
\text { Britt. and Rose }\end{array}$ \\
\hline $82-546$ & $\mathrm{~h}+$ & Fox Bay, Montserrat & C. royenii \\
\hline $82-548 A$ & $h+$ & Fox Bay, Montserrat & C. royenii \\
\hline $82-550 \mathrm{~A}$ & Diploid & Airport, Montserrat & C. royenii \\
\hline $82-556 \mathrm{C}$ & $h+$ & Airport, Montserrat & C. royenii \\
\hline $82-558$ & $\mathrm{~h}-$ & Airport, Montserrat & C. royenii \\
\hline $82-562 A$ & $\mathrm{~h}-$ & Airport, Montserrat & C. royenii \\
\hline $82-563 A$ & h+ & Airport, Montserrat & C. royenii \\
\hline $82-568 B$ & & Airport, Montserrat & C. royenii \\
\hline $82-589 B$ & Diploid & $\begin{array}{l}\text { Beef Island, Tortola, } \\
\text { Virgin Islands }\end{array}$ & C. royenii \\
\hline $82-592 B$ & $\mathrm{~h}+$ & $\begin{array}{l}\text { Beef Island, Tortola, } \\
\text { Virgin Islands }\end{array}$ & C. royenii \\
\hline $82-603 A$ & $h+$ & $\begin{array}{l}\text { Beef Island, Tortola, } \\
\text { Virgin Islands }\end{array}$ & C. royenii \\
\hline $82-604 B$ & $h+$ & $\begin{array}{l}\text { Beef Island, Tortola, } \\
\text { Virgin Islands }\end{array}$ & C. royenii \\
\hline $82-616 B$ & Diploid & $\begin{array}{l}\text { Beef Island, Tortola, } \\
\text { Virgin Islands }\end{array}$ & C. royenii \\
\hline $82-628 B$ & $h-$ & $\begin{array}{l}\text { Pricklypear Island, } \\
\text { Virgin Gorda, Vir- } \\
\text { gin Islands }\end{array}$ & C. royenii \\
\hline $82-631 A$ & $\mathrm{~h}+$ & $\begin{array}{l}\text { Pricklypear Island, } \\
\text { Virgin Gorda, Vir- } \\
\text { gin Islands, }\end{array}$ & C. royenii \\
\hline $82-637 A$ & $\mathrm{~h}-$ & $\begin{array}{l}\text { Pricklypear Island, } \\
\text { Virgin Gorda, Vir- } \\
\text { gin Islands }\end{array}$ & C. royenii \\
\hline $82-647 B$ & $\mathrm{~h}+$ & $\begin{array}{l}\text { Pricklypear Island, } \\
\text { Virgin Gorda, Vir- } \\
\text { gin Islands }\end{array}$ & $\begin{array}{l}\text { Melocactus intortus } \\
\text { Urban }\end{array}$ \\
\hline $82-651 A^{\mathrm{T} b}$ & Diploid & $\begin{array}{l}\text { Pricklypear Island, } \\
\text { Virgin Gorda, Vir- } \\
\text { gin Islands }\end{array}$ & C. royenii \\
\hline 82-651D & h- & $\begin{array}{l}\text { Pricklypear Island, } \\
\text { Virgin Gorda, Vir- } \\
\text { ginia Islands }\end{array}$ & C. royenii \\
\hline
\end{tabular}

" UCD-FST, Department of Food Science and Technology, University of California, Davis.

${ }^{b} \mathrm{~T}=$ type strain.

vexa, nitida, glabra, mollis, cremea; margo glabra aut lobata.

In agaro farinae Zea mays post dies 10 pseudomycelium nullum.

Species heterothallica haploidea aut raro diploidea. Oriuntur asci ex conjugatione inter cellulas sexus contrarii; asci ex cellulae diploidae inconjuganti fiunt, habentes 4 sporas pileiformae; asci rumpunter post dies 3-5.

Fermentatio glusosi nullum.

Glucosum, rhamnosum (lente), ethanolum, glycerolum, mannitolum (lente, exigue, vel nullum), glucono-delta-lactonum (lente et exigue), acidum lacticum, acidum succinicum, et acidum citricum (valde) assimilantur at non galactosum, L-sorbosum, maltosum, saccharum, cellobiosum, trehalosum, lactosum, melibiosum, raffinosum, melezitosum, inulinum, amylum solubile, D-xylosum, L-arabinosum, D-arabinosum, D-ribosum, methanolum, erythritolum, ribitolum, galactitolum, D-glucitolum, salicinum, $\alpha$-methyl-Dglucosidum, 2- et 5-ketogluconatum, D-glucosaminum, $\mathrm{N}$ acetyl-glucosaminum, acetonum, 2-propanolum, ethylacetas, nec inositolum.

Kalium nitricum et natrium nitrosum non assimilantur.

Ethylaminum assimilatur.
Ad crescentiam biotinum, thiaminum, et pyridoxinum necessariae sunt.

Crescere potest in $36^{\circ} \mathrm{C}$ interdum in $39^{\circ} \mathrm{C}$.

$\mathrm{G}+\mathrm{C}$ acidi deoxyribonucleati, $33.4-33.7$ mol\% (6 stirpes) (Table 2).

Habitatio cacto.

Typus: stirps UCD-FST 82-651A ex tabidosus sacculis cacti Cephalocereus royenii isolata est.

In collectione zymotica Centraalbureau voor Schimmelcultures, Delphi Batavorum, sub no. (7111) deposita est.

Standard description of Pichia antillensis. In malt extract after 3 days at $25^{\circ} \mathrm{C}$, the cells are globose to ovoid to short ovoid and 1.6 to 5.3 by 2.1 to $5.8 \mu \mathrm{m}$ and occur singly, in pairs, or in groups of three to seven cells. There is little sediment, a thin ring, and sometimes a very thin pellicle or islets after 7 days.

On malt agar after 2 weeks at $25^{\circ} \mathrm{C}$, streak cultures are low convex, glossy, smooth, soft, and white. The periphery is entire to slightly lobular.

In Dalmau plate cultures on cornmeal agar after 10 days a pseudomycelium is absent; outgrowths of clusters of cells are occasionally present.

The vegetative cells are heterothallic, usually occurring in the haploid state when isolated from nature but occasionally occurring in the diploid state. Conjugation and sporulation are observed on Difco YM agar at $25^{\circ} \mathrm{C} 3$ to 5 days after the appropriate mating types have been mixed together. Ascospores are usually formed in diploid cells that bud from the zygotes. The spores are derby hat shaped, and usually four are produced per ascus. Asci from diploid strains, each containing four spores, have been dissected; these asci yield two spores of one mating type and two spores of the opposite mating type. The asci dehisce rapidly, releasing the spores soon after formation.

Ability to ferment glucose is absent. The carbon compounds D-Glucose, L-rhamnose (latent), ethanol, glycerol, D-mannitol (latent, weak, or negative), glucono- $\delta$-lactone (latent and weak), DL-lactic acid, succinic acid, and citric acid (strong) are assimilated. The following carbon compounds are not assimilated: D-galactose, L-sorbose, maltose, sucrose, cellobiose, trehalose, lactose, melibiose, raffinose,

TABLE 2. Nuclear DNA base compositions ( $\mathrm{G}+\mathrm{C}$ contents) of $P$. antillensis strains and other species used in DNA-DNA reassociation studies

\begin{tabular}{|c|c|c|}
\hline $\begin{array}{l}\text { UCD-FST } \\
\text { strain no }\end{array}$ & Organism & $\begin{array}{l}\mathrm{G}+\mathrm{C} \\
\text { content } \\
\text { (mol\%) }\end{array}$ \\
\hline $82-651 A^{T}$ & $P$. antillensis & $33.7 \pm 0.3^{a}$ \\
\hline $82-637 \mathrm{~A}$ & $P$. antillensis & $33.5 \pm 0.1$ \\
\hline $82-628 B$ & $P$. antillensis & $33.7 \pm 0.3$ \\
\hline $82-604 \mathrm{~B}$ & $P$. antillensis & $33.4 \pm 0.2$ \\
\hline $82-589 B$ & $P$. antillensis & $33.6 \pm 0.2$ \\
\hline $82-550 \mathrm{~A}$ & P. antillensis & $33.4 \pm 0.2$ \\
\hline $76-356^{\mathrm{T}}$ & $P$. heedii & $32.4 \pm 0.2$ \\
\hline $76-401 B^{T}$ & P. amethionina var. amethionina & $33.1 \pm 0.1$ \\
\hline $76-384 \mathrm{~A}^{\mathrm{T}}$ & $P$. amethionina var. pachycereana & $33.0 \pm 0.2$ \\
\hline $79-132 \mathrm{D}$ & P. amethionina (from Australia) & $32.3 \pm 0.5$ \\
\hline $81-62$ & $P$. amethionina (from Bahamas) & $34.3 \pm 0.1$ \\
\hline $77-40^{\mathrm{T}}$ & $P$. opuntiae var. opuntiae & $33.4 \pm 0.5$ \\
\hline $77-159$ & P. opuntiae var. opuntiae & $33.0 \pm 0.1$ \\
\hline $76-211^{\mathrm{T}}$ & $P$. opuntiae var. thermotolerans & $33.0 \pm 0.3$ \\
\hline $76-41$ & $\begin{array}{l}\text { Metschnikowia bicuspdata var. } \\
\text { bicuspidata }\end{array}$ & $47.0 \pm 0.3$ \\
\hline
\end{tabular}

${ }^{a}$ Average \pm standard deviation from three or more buoyant density determinations. 
TABLE 3. Reannealing between labeled DNA from $P$. antillensis UCD-FST $82-651 \mathrm{~A}^{\mathrm{T}}$ and DNAs from 14 yeast strains and calf thymus at $61.4^{\circ} \mathrm{C}^{\prime \prime}$

\begin{tabular}{|c|c|c|c|c|c|c|}
\hline \multirow[b]{2}{*}{ Organism or tissue } & \multicolumn{3}{|c|}{ Expt 1} & \multicolumn{3}{|c|}{ Expt 2} \\
\hline & $\begin{array}{l}\text { Actual binding } \\
(\%)^{b}\end{array}$ & $\begin{array}{l}\text { Corrected actual } \\
\text { bịnding }(\%)^{\circ}\end{array}$ & $\begin{array}{c}\text { Relative } \\
\text { binding }(\%)^{r}\end{array}$ & $\begin{array}{c}\text { Actual } \\
\text { binding }(\%)^{h}\end{array}$ & $\begin{array}{l}\text { Corrected actual } \\
\text { binding }(\%)^{\circ}\end{array}$ & $\begin{array}{c}\text { Relative } \\
\text { binding }(\%)^{c}\end{array}$ \\
\hline P. antillensis UCD-FST $82-651 \mathrm{~A}^{\mathrm{T}}$ & $78.6 \pm 0.5^{d}$ & 75.9 & 100.0 & $75.7 \pm 0.9$ & 75.2 & 100.0 \\
\hline P. antillensis UCD-FST 82-628B & $77.6 \pm 0.9$ & 74.9 & 98.8 & & & \\
\hline$P$. antillensis UCD-FST 82-589B & $78.5 \pm 0.9$ & 75.9 & 99.9 & & & \\
\hline P. antillensis UCD-FST $82-550 \mathrm{~A}$ & $77.6 \pm 1.8$ & 75.0 & 98.8 & $72.4 \pm 0.8$ & 71.8 & 95.5 \\
\hline P. antillensis UCD-FST 82-637A & & & & $72.7 \pm 1.1$ & 72.1 & 95.9 \\
\hline P. opuntiae var. opuntiae UCD-FST $77-40^{\mathrm{T}}$ & & & & $42.7 \pm 2.0$ & 41.5 & 55.2 \\
\hline P. opuntiae var. opuntiae UCD-FST 77-159 & & & & $42.1 \pm 1.8$ & 40.9 & 54.4 \\
\hline $\begin{array}{l}\text { P. opuntiae var. thermotolerans UCD-FST } \\
76-211^{\mathbf{T}}\end{array}$ & & & & $21.4 \pm 1.7$ & 19.8 & 26.4 \\
\hline P. heedii UCD-FST $76-356^{\mathrm{T}}$ & $5.0 \pm 0.1$ & 2.1 & 2.8 & & & \\
\hline $\begin{array}{l}P . \text { amethionina var. amethionina UCD-FST } \\
76-401 \mathrm{~B}^{\mathrm{T}}\end{array}$ & $9.5 \pm 1.2$ & 6.6 & 8.7 & & & \\
\hline $\begin{array}{l}\text { P. amethionina var. pachycereana UCD- } \\
\text { FST } 76-384 \mathrm{~A}^{\mathrm{T}}\end{array}$ & $9.2 \pm 1.5$ & 6.4 & 8.4 & & & \\
\hline $\begin{array}{l}\text { P. amethionina UCD-FST 79-132D (from } \\
\text { Australia) }\end{array}$ & $8.0 \pm 0.4$ & 5.1 & 6.7 & $8.3 \pm 0.9$ & 6.5 & 8.6 \\
\hline $\begin{array}{l}\text { P. amethionina UCD-FST 81-62 (from } \\
\text { Bahamas) }\end{array}$ & $7.4 \pm 0.3$ & 4.5 & 5.9 & & & \\
\hline Metschnikowia bicuspidata UCD-FST 76-41 & $3.2 \pm 0.4$ & 0.3 & 0.4 & & & \\
\hline Calf thymus & $4.1 \pm 0.2$ & 1.2 & 1.6 & $3.5 \pm 1.0$ & 1.6 & 2.1 \\
\hline
\end{tabular}

" 125I-labeled DNA $(0.2 \mu \mathrm{g})$ and unlabeled DNA $(200 \mu \mathrm{g})$ were incubated for $25 \mathrm{~h}$ in $0.5 \mathrm{ml}$ of $280 \mathrm{mM}$ phosphate buffer.

${ }^{h}$ Average of three samples corrected for zero-time binding.

Corrected for self-renaturation (experiment $1,2.9 \pm 0.5 \%$; experiment $2,2.0 \pm 0.6 \%$ ) (10).

"Mean \pm standard deviation.

melezitose, inulin, soluble starch, D-xylose, L-arabinose, Darabinose, D-ribose, methanol, erythritol, ribitol, galactitol, D-glucitol, salicin, methyl- $\alpha$-D-glucoside, 2- and 5-ketogluconate, D-glucosamine, meso-inositol, ethyl acetate, acetone, 2-propanol, hexadecane, and $N$-acetyl-D-glucosamine.

Assimilation of nitrogen compounds: potassium nitrate, negative; sodium nitrite, negative; ethylamine, positive; lysine, positive; cadaverine, positive; ammonium sulfate, positive.

Growth in vitamin-free medium is negative. Biotin, thiamine, and pyridoxine are required for growth.

Growth in amino acid-free medium is positive.

Growth on $50 \%(\mathrm{wt} / \mathrm{wt})$ glucose-yeast extract agar is negative.

Growth on glucose-yeast extract agar containing $5 \% \mathrm{NaCl}$ is positive; growth on the same medium containing $7.5 \%$ $\mathrm{NaCl}$ is weak; and growth in the presence of $10 \% \mathrm{NaCl}$ is negative.

Maximum temperature for growth, 36 to $39^{\circ} \mathrm{C}$ (depending on the strain).

No acid formation on chalk agar.

Hydrolysis of urea, negative.

Gelatin liquefaction, negative.

Casein hydrolysis, negative.

Lipolytic activity, negative.

Growth in the presence of $1 \mu \mathrm{g}$ of cycloheximide per $\mathrm{ml}$, positive; growth in the presence of $10 \mu \mathrm{g}$ of cycloheximide per $\mathrm{ml}$, negative.

$\mathrm{G}+\mathrm{C}$ content of the nuclear DNA, 33.4 to $33.7 \mathrm{~mol} \%$ (six strains) (Table 2).

Habitat. A total of 20 strains were recovered from necrotic tissue of $C$. royenii on the West Indian islands of Montserrat, Tortola, and Virgin Gorda; 1 strain was recovered from necrotic tissue of Melocactus intortus on Virgin Gorda.

Type. The type strain of $P$. antillensis, strain UCD-FST 82-651A, was isolated from a rot of $C$. royenii on the island of Virgin Gorda in the Lesser Antilles, West Indies. This strain has been deposited in the collection of the Yeast Division of the Centraalbureau voor Schimmelcultures in Delft, The Netherlands, as strain CBS 7111 and in the American Type Culture Collection, Rockville, Md., as strain ATCC 56267.

Etymology. The specific epithet of $P$. antillensis (an. til. len' sis. M.L.f. adj. antillensis) is geographical, referring to the occurrence of this organism on islands of the Antilles, West Indies.

\section{DISCUSSION}

Investigations into the yeast communities associated with the decaying stems of cacti have revealed a group of yeasts which share certain physiological, ecological, and macromolecular properties. These species include $P$. heedii Phaff et al. (9), two varieties of $P$. amethionina Starmer et al. (13), two varieties of $P$. opuntiae Starmer et al. (14), and $P$. antillensis. These species are heterothallic and have similar low-level physiological abilities and DNA base compositions ( $\mathrm{G}+\mathrm{C}$ contents) clustered in a 2.0 -mol\% range (32.3 to 34.3 $\mathrm{mol} \%$ ). However, they do not conjugate in the laboratory when haploid mating types of the respective species are mixed.

A previous study on the DNA-DNA base sequence relatedness of $P$. heedii, $P$. amethionina, and $P$. opuntiae clearly demonstrated the distinct genomic separation of these three species (3). This study also demonstrated a significant sequence divergence between the two varieties of $P$. amethionina, as well as the unreliability of using mannitol assimilation as a means of separating these varieties. The mean intervarietal relative binding to hydroxylapatite of the DNAs of the two varieties of $P$. opuntiae was $28.0 \pm 3.1 \%$ based on five pair-wise comparisons (3); this, together with the lack of gene flow between the organisms $(8,14)$, suggests that they represent distinct biological species.

Table 4 lists the known differences among the four Pichia species, including the previously described varieties of these species. These data show that the only phenotypic differ- 
TABLE 4. Salient characteristics differentiating $P$. antillensis from several phenotypically similar cactus-associated yeasts ${ }^{a}$

\begin{tabular}{|c|c|c|c|c|c|c|}
\hline Characteristic & P. antillensis & $\begin{array}{l}\text { P. opuntice } \\
\text { var. opunticle }\end{array}$ & $\begin{array}{l}\text { P. opuntiae } \\
\text { var. } \\
\text { thermotolerans }\end{array}$ & $\begin{array}{c}\text { P. amethionina } \\
\text { var. } \\
\text { amethionina }\end{array}$ & $\begin{array}{c}\text { P. amethionina } \\
\text { var. } \\
\text { pachycereana }\end{array}$ & P. heedii \\
\hline \multicolumn{7}{|l|}{ Growth at: } \\
\hline $33^{\circ} \mathrm{C}$ & $+^{b}$ & $+1-$ & + & + & + & + \\
\hline $37^{\circ} \mathrm{C}$ & $+1-$ & - & + & + & + & + \\
\hline $39^{\circ} \mathrm{C}$ & $+1-$ & - & - & + & + & + \\
\hline $42^{\circ} \mathrm{C}$ & - & - & - & $+1-$ & $+1-$ & $+1-$ \\
\hline \multicolumn{7}{|l|}{ Growth on: } \\
\hline Cellobiose & -. & $1 /-$ & + & - & - & - \\
\hline D-Xylose & - & - & - & - & - & + \\
\hline L-Rhamnose & 1 & $1 / w$ & $1 / w$ & - & - & - \\
\hline D-Mannitol & $1 / w /-$ & $1 /-$ & 1 & $-1+$ & + & - \\
\hline Salicin & - & + & + & - & - & - \\
\hline D-Gluconate & - & - & - & + & + & - \\
\hline Citrate & + & + & - & - & - & $+1-$ \\
\hline Requires L-methionine & - & - & - & + & + & - \\
\hline $\begin{array}{l}\text { Growth in the presence of } 1 \mu \mathrm{g} \text { of } \\
\text { cycloheximide per ml }\end{array}$ & + & - & - & - & - & - \\
\hline $\begin{array}{l}\text { Growth in the presence of } 10 \mu \mathrm{g} \text { of } \\
\text { cycloheximide per ml }\end{array}$ & - & - & - & - & - & - \\
\hline Ascus dehiscence & $\mathrm{rp}$ & $\mathrm{rp}$ & $\mathrm{rp}$ & $\mathrm{rp}$ & $\mathrm{rp}$ & sl \\
\hline $\mathrm{G}+\mathrm{C}$ content $(\mathrm{mol} \%)$ & $33.6 \pm 0.14^{\circ}$ & $33.6 \pm 0.25$ & $33.1 \pm 0.23$ & $33.1 \pm 0.05$ & $33.1 \pm 0.32$ & $32.5 \pm 0.14$ \\
\hline
\end{tabular}

"The following compounds are assimilated by all four species: glucose, ethanol, glyerol, lactate, and succinate. No other compound used in standard assimilation tests (16) is assimilated by these four species.

$b+$, Positive; - , negative; 1 , latent growth; $w$, weak growth; $+/-$, some strains negative; $-1+$, some strains positive; $1 / w-$, strain dependent; rp, rapid; sl, slow (well after maturation).

c Mean \pm standard deviation.

ences known between $P$. antillensis and $P$. opuntiae var. opuntiae are the ability of the latter to utilize salicin as a carbon source and the ability of $P$. antillensis to grow in the presence of $1 \mu \mathrm{g}$ of cycloheximide per $\mathrm{ml}$. The assimilation of L-rhamnose by $P$. antillensis might be easily overlooked. On yeast nitrogen base agar it usually takes from 7 to 9 days before small colonies appear. However, when rhamnosegrown cells are reinoculated into fresh yeast nitrogen base medium containing rhamnose (solid or liquid), full growth takes place in 2 to 5 days, suggesting that the enzymes involved in rhamnose metabolism are inducible.

The DNA-DNA reassociation data show (Table 3) that $P$. antillensis shares approximately $50 \%$ of its base sequences with $\boldsymbol{P}$. opuntiae var. opuntiae. DNA-DNA reassociation values of about $50 \%$ are very rare among yeast species (10), but this relatively high DNA complementarity between the two yeasts indicates a significant relatedness. The complete lack of conjugation in laboratory experiments between mating types of the two species could be due to mutations in one or more genes that control the formation of zygotes (prezygotic breakdown). Such changes may have developed as a result of the reproductive isolation of $P$. antillensis and $P$. opuntiae (8). So far, $P$. opuntiae var. opuntiae has been found only in necrotic tissues of Australian opuntias $(1,14)$, the exact origin of which is not known in detail (7), although it is known that they were imported from the Americas into Australia within the last 200 years $(1,7)$. Extensive sampling of Opuntia species in Arizona and Texas (12), as well as on a number of islands in the Caribbean Sea (Starmer and Phaff, unpublished data), including those on which we discovered $P$. antillensis, failed to yield typical strains of $P$. opuntiae var. opuntiae. The lack of discovery of the latter in the New World may be due to insufficient sampling, such as the omission of South American opuntias. We postulate that $P$. antillensis and $\boldsymbol{P}$. opuntiae var. opuntiae originated from a common ancestor and that both allopatry and differences in host plant chemistry $(C$. royenii $[P$. antillensis] and Opuntia inermis ( $P$. opuntiae var. opuntiae]) have played a role in their evolutionary divergence. A resolution of the problem of the relationship between the two species will require further study of characters, such as analysis of allozymes (4) and specific DNA sequences or both.

\section{ACKNOWLEDGMENTS}

This work was supported by grants DEB 81-08679 (to W.T.S.) and DEB 81-08898 (to H.J.P.) from the National Science Foundation.

\section{LITERATURE CITED}

1. Barker, J. S. F., G. L. Toll, P. D. East, M. Miranda, and H. J. Phaff. 1983. Heterogeneity of the yeast flora in the breeding sites of cactophilic Drosophila. Can. J. Microbiol. 29:6-14.

2. Fowell, R. R. 1969. Sporulation and hybridization of yeasts, p. 303-383. In A. H. Rose and J. S. Harrison (ed.), The yeasts, vol. 1. Academic Press, Inc., New York.

3. Holzschu, D. L., and H. J. Phaff. 1982. Taxonomy and evolution of some ascomycetous cactophilic yeasts, p. 127-141. In J. S. F. Barker and W. T. Starmer (ed.), Ecological genetics and evolution, the cactus-yeast-Drosophila model system. Academic Press Australia, Sydney.

4. Holzschu, D. L., H. J. Phaff, J. Tredick, and D. Hedgecock. 1983. Pichia pseudocactophila, a new species of yeast occurring in necrotic tissue of columnar cacti in the North American Sonoran Desert. Can. J. Microbiol. 29:1314-1322.

5. Holzschu, D. L., H. L. Presley, M. Miranda, and H. J. Phaff. 1979. Identification of Candida lusitaniae as an opportunistic yeast in humans. J. Clin. Microbiol. 10:202-205.

6. Marmur, J. 1961. A procedure for the isolation of DNA from microorganisms. J. Mol. Biol. 3:208-218.

7. Murray, N. D. 1982. Ecology and evolution of the OpuntiaCactoblastis ecosystem in Australia, p. 17-30. In J. S. F. Barker and W. T. Starmer (ed.), Ecological genetics and evolution, the cactus-yeast-Drosophila model system. Academic Press Australia, Sydney.

8. Phaff, H. J. 1980. The species concept in yeast: physiologic, morphologic, genetic, and ecological parameters, p. 635-643. In G. G. Stewart and I. Russell (ed.), Current developments in yeast research. Pergamon Press, Toronto. 
9. Phaff, H. J., W. T. Starmer, M. Miranda, and M. W. Miller. 1978. Pichia heedii, a new species of yeast indigenous to necrotic cacti in the North American Sonoran Desert. Int. J. Syst. Bacteriol. 28:326-331.

10. Price, C. W., G. B. Fuson, and H. J. Phaff. 1978. Genome comparison in yeast systematics: delimitation of species within the genera Schwanniomyces, Saccharomyces, Debaryomyces, and Pichia. Microbiol. Rev, 42:161-193.

11. Schildkraut, C. L., J. Marmur, and P. Doty. 1962. Determination of the base composition of deoxyribonycleic acid from its buoyant density in CsCl. J. Mol. Biol. 4:430-433.

12. Starmer, W. T., and H. J. Phaff. 1983. Analysis of the community structure of yeasts associated with the decaying stems of cactus. II. Opuntia species. Microb. Ecol. 9:247-259.
13. Starmer, W. T., H. J. Phaff, M. Miranda, and M. W. Miller. 1978. Pichia amethionina, a new heterothallic yeast associated with decaying stems of cereoid cacti. Int. J. Syst. Bacteriol. 28:433-441.

14. Starmer, W. T., H. J. Phaff, M. Miranda, M. W. Miller, and J. S. F. Barker. 1979. Pichia opuntiae, a new heterothallic species of yeast found in decaying cladodes of Opuntia inermis and in necrotic tissue of cereoid cacti. Int. J. Syst. Bacteriol. 29:159-167.

15. Szybalski, W. 1969. Use of cesium sulfate for equilibrium density gradient centrifugation. Methods Enzymol. 12:330-360.

16. van der Walt, J. P. 1970. Criteria and methods used in classification, p. 34-113. In J. Lodder (ed.), The yeasts-a taxonomic study. North-Holland Publishing Co., Amsterdam. 